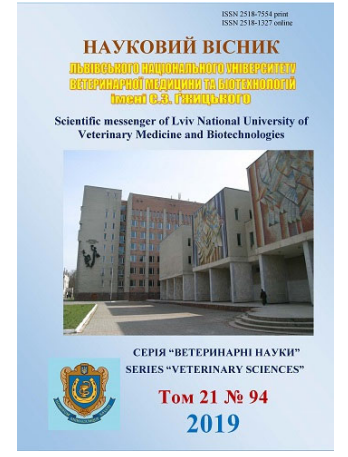

\section{Науковий вісник Иьвівського націонадьного університету ветеринарної медицини та біотехнологій імені С.3. Гжицького.}

\author{
Серія: Ветеринарні науки
}

\section{Scientific Messenger of Lviv National University of Veterinary Medicine and Biotechnologies. Series: Veterinary sciences}

ISSN 2518-7554 print ISSN 2518-1327 online doi: $10.32718 /$ nvlvet 9407

http://nvlvet.com.ua

UDC 591.5:(639.1: 574.91)+599.744.427

\title{
Ecological and epizootic roles of Golden jackal, genus Canis aureus in the Northwest of Black Sea coast
}

\author{
I.V. Nakonechnyi ${ }^{1}$, L.V. Perots'ka ${ }^{2}$ I.V. Pyvovarova ${ }^{2}$, V.A. Chornyi ${ }^{2}$ \\ ${ }^{1}$ National Shipbuilding University named after Admiral Makarov, Mykolayiv, Ukraine \\ ${ }^{2}$ Odessa State Agrarian University, Odessa, Ukraine
}

\section{Article info}

Received 25.03.2019

Received in revised form 25.04.2019

Accepted 26.04.2019

National Shipbuilding University named after Admiral Makarov Prospect Heroes of Ukraine, 9 , Mykolayiv, 54025, Ukraine.

Odessa State Agrarian University, St. Panteleimonivs'ka, 13, Odessa, 65012, Ukraine. Tel: $+38-067-785-61-94$ E-mail:perotskaya@ukr.net
Nakonechnyi I.V., Perots'ka L.V., Pyvovarova I.V., \& Chornyi V.A. (2019). Ecological and epizootic roles of Golden jackal, genus Canis aureus in the Northwest of Black Sea coast. Scientific Messenger of Lviv National University of Veterinary Medicine and Biotechnologies. Series: Veterinary sciences, 21(94), 37-43. doi: 10.32718/nvlvet9407

Penetration of jackal, typical representative of Asia Minor-Balkan group, genus Canis aureus into the territory of the Northwest Black Sea coast - has become a rather unexpected phenomenon and led to environmental, zoogeographical and epizootic issues. The last one may lead to the development of potentially dangerous epizootic processes, the assessment of the threat and possible consequences require systematic researches. The purpose of this work was to study the ecological and epizootic role of Canis aureus in the territory of the Northwest Black Sea coast. The investigations concerning epizootic status of jackal were carried out during 2014-2018 in the territory of Odesa and Mykolayiv Regions with means of laboratory control samples of the materials which were selected and taken from hunters. The results of researches have shown that there is a complete, self-regulating and rather dense population of C. aureus in this region, it does not lose the rate of intensive reproduction and has a clearly expressed western line of genus penetration. In the process of migratory settlement, jackal demonstrates clear and static dependences on humidified and hydro morphed landscapes. When the bodies of animals were observed, we could find the presence of ticks and several types of fleas that could act as a biological transmission objects in the circles of spontaneous circulation of naturally occurring zoonotic pathogens, ensuring their inter-species migration and short-term reservation. According to the results of laboratory examinations of 9 samples of jackals' blood serum, the presence of antibodies to the causative agent of erysipelas was determined in 5 (55.5\%) cases. In response to a single brucellosis antigen The specific antibodies were not found in the reaction with single brucellosis antigen. The investigations on the presence of leptospirosis were carried out with test strains of 9 serogroups. Specific anti-lepidopteran antibodies were found in all investigated serum samples. The predominance of antibodies to the Grippotyphosa, Hebdomadis, Sejroe, Bataviae serogroups, mice field rodents are their host, indicates the trophic nature of antigenic contacts. The new species for Ukrainejackal Cainis aureus carries a significant potential epizootic threat as a host and carrier of pathogens natural-focal zoonotic infections and invasions, the most dangerous among them is rabies.

Key words: ecosystem, fauna, enzootic nosological entity, Golden jackal, zoonosis, naturally-focal infection, ectoparasite, antibody.

\section{Еколого-епізоотична роль шакала звичайного Canis aureus у Північно- Західному Причорномор'ї}

\author{
I.В. Наконечний ${ }^{1}$, Л.В. Пероцька ${ }^{2}$ І І.В. Пивоварова ${ }^{2}$, В.А. Чорний ${ }^{2}$ \\ ${ }^{1}$ Національний університет кораблебудування ім. адмірала Макарова, м. Миколоїв, Украӥна \\ ${ }^{2}$ Одеський державний аграрний університет, м. Одеса, Украӥна
}


Проникнення на територію Північно-Західного Причорномор'я типового представника малоазійсько-балканської групи видів Cапіs aureus стало доволі неочікуваним явищем і спричинило низку екологічних, зоогеографічних та епізоотичних питань. Останні несуть очікування розвитку потениійно небезпечних епізоотичних прочесів, очінка загрози яких та можливі наслідки вимагають системних досліджень. Метою даної роботи стало вивчення еколого-епізоотичної ролі Сапіs аитеиs на території ПівнічноЗахідного Причорномор'я. Дослідження щзодо епізоотичного статусу шакала були виконані в 2014-2018 рр. на території Одеської та Миколаӥвської областей шляхом лабораторного контролю проб матеріалу, відібраного від здобутих мисливиями особин. Результати досліджень свідчать, щзо в даному регіоні існує повноцінна саморегулююча і досить щзільна популяція С. аигеия, яка не втрачає темпів інтенсивного розмноження $і$ має явно виражену західну магістраль проникнення виду. У процесі міграційного розселення шакал демонструє чітку стаціальну залежність від зволожених $і$ гідроморфних ландшафтів. При огляді тіл здобутих тварин знаходили кліщів та кілька видів бліх, щзо можуть виступати як об'єкти біологічної трансмісії в колах спонтанної циркуляиії збудників природно-осередкових зоонозів, забезпечуючи їх міжвидову міграцію та короткочасну резервацію. За результатами лабораторних експертиз 9-ти проб сироваток крові шакалів встановлена наявність антитіл до збудника бешихи в 5 (55,5\%) випадках. В реакиії з єдиним бруцельозним антигеном специфічних антитіл не виявлено. Дослідження на лептоспіроз проводили з тест-итамами 9-ти серогруп. Специфічні протилептоспірозні антитіла виявлені в усіх досліджених пробах сироваток. Переважання антитіл до серогруn Grippotyphosa, Hebdomadis, Sejroe, Ватаviae, хазяями яких є мишовидні польові гризуни, вказує на трофічну природу антигенних контактів. Новий для Украӥни вид - шакал Сапіs аитеиs несе значний потенціал епізоотичної загрози як хазяїн і носій збудників природно-осередкових зоонозних інфекцій та інвазій, найбільи небезпечним з яких є сказ.

Ключові слова: екосистема, фауна, ензоотичні нозоформи, иакал звичайний, зооноз, природно-осередкова інфекиія, ектопаразит, антитіло.

\section{Вступ}

Степові фауністичні комплекси Південної України $\epsilon$ значно відмінними від складу фауни сусідньої Середземноморської підобласті Голарктичної зоогеографічної області (Kucheruk, 1959), цим самим визначаючи i відповідну специфіку місцевих паразитоценозів. Степова біота містить значну частку спеціалізованих стенотопних видів із власним паразитарним шлейфом, але основні ензоотичні нозоформи Степу переважно пов'язані з екологічно пластичними транспалеарктами (заєць-русак L. europaeus, хом'як звичайний C. cricetus, вовк C. lupus, лисиця $V$. vulpes, борсук M. meles, куницякам'янка $M$. foina, ласка $M$. nivalis, горностай M. erminea). В міру агрогенної та антропогенної трансформації степів почалось проникнення у південні райони численних алохтонів (лісові види полівок Clethrionomys, козуля C. capreolus, кабан S. scrofa, білка Sc. vulgaris, ондатра On. zibethicus, миша-житник $A$. agrarius). Вказані види, разом із аборигенами степової зони, формують змішаний характер фауністичних угруповань, що різко розширює та ускладнює видові взаємозв'язки місцевих паразитоценозів (Nakonechnyi, 2007; Nakonechnyi, 2012).

Яскравим прикладом цього $є$ проникнення на територію Північного Причорномор'я типового представника малоазійсько-балканської групи видів Canis aureus, що стало доволі неочікуваним явищем і спричинило низку екологічних, зоогеографічних та епізоотичних питань. Останні загрожують розвитком потенційно небезпечних епізоотичних процесів, оцінка загрози яких та можливі наслідки вимагають системних досліджень. Особливо загрозливим та екологічно незрозумілим стало стрімке поширення цього досить великого хижака саме в умовах суцільно трансформованого природного середовища регіону. Відсутні навіть чіткі позиції щодо палеоареалу шакала та індикації його кісткових решток на Півдні України хоча б впродовж історичного періоду, тимчасом як “поряд” - на Балканах, вид фіксований від середнього плейстоцену донині (Kirikov, 1959; Kuznecov, 1975; David, 1982).

Степи Північно-Західного Причорномор'я, розташовані на прибережних рівнинах Одеської, Миколаївської, Херсонської та Запорізької областей, загалом $є$ зразком відкритих ландшафтів аридного типу. Останні майже непридатні для існування шакала, який тяжіє до гідроморфних інтразональних біотопів та мозаїчного передгірного ландшафту (Okulova et al., 2016), тому й можливість існування шакала на півдні України пов'язана саме 3 приморськими ландшафтами та долинами і плавнями степових річок. Окрім цього, в регіоні розташовані потужні дельтові зони Дунаю, Дністра та Дніпра, узбережжя між якими розкроєне численними лиманами. Тож сучасна територія Північно-Західного Причорномор'я в стаціальному розумінні $\epsilon$ потенційною ареною формування нової, але стабільно стійкої популяції шакала, а 3 нею й розширення структури інфекційних i паразитарних хвороб, збудники яких пов'язані з цим видом. Все це свідчить про неабияку епізоотичну загрозу, яку несе для степової України проникнення та закріплення в місцевій фауні нового виду - шакала звичайного. Відповідно метою даної роботи стало вивчення еколого-епізоотичної ролі Canis aureus на території Північно-Західного Причорномор'я.

Аналіз останніх публікацій. Перші повідомлення про знаходження в дельтовій зоні Дністра (на території України) шакала Canis aureus мали місце у 1998 році, що наведено в роботах А.М. Волоха та М.В. Роженка, які й надалі успішно займались вивченням цього виду (Rozhenko and Voloh, 2000; Voloh, 2004; Voloh, 2014; Rozhenko, 2017). У 2006 році були підтверджені перші випадки зустрічі шакала в Закарпатті та Миколаївській області - в прибережно-прилиманських місцевостях Березанського та Очаківського районів, а з 2012 р. - в правобережних плавнях Нижнього Побужжя (Potish, 2006; Redinov, 2015). Згідно з даними А.М. Волоха, процес розширення ареалу не втрачає темпів - в останні роки шакал проник у північно-східні області 
України, в Польщу, Естонію та Литву. В Україні на початок 2016 р. успішно функціонували чотири розрізнених осередки існування виду, а саме: на узбережжі Дунай-Дністер-Дніпровського межиріччя, на території материкового і кримського Присивашшя, на півострові Бірючий та на річкових островах Дніпра, південніше міста Запоріжжя (Voloh, 2014).

Виникнення та стабільність цих осередків $\epsilon$ свідченням неухильної тенденції північного розширення ареалу виду (Domnich et al., 2009), який i досі успішно освоює вільні екологічні ніші в антропогенно порушених екосистемах. Наявність в північному Причорномор’ї носіїв панівних генотипів i3 балканського та кавказького осередків, що підтверджено специфікою їхніх гаплогруп, вказує на змішане, балкансько-кавказьке походження новосформованої популяції (Dzuev et al., 2011; Voloh, 2014).

\section{Матеріал і методи досліджень}

При підготовці даної статті як базисний матеріал слугували результати власних досліджень, поєднані 3 фактичними матеріалами, взятими зі спеціальної літератури, картографічні дані. Безпосередні дослідження щодо епізоотичного статусу шакала Canis aureus були виконані в 2014-2018 pp. на території Одеської та Миколаївської областей шляхом лабораторного контролю проб матеріалу, відібраного від 11 здобутих мисливцями особин виду. Вказані дослідження охоплювали лише незначну площу території сучасного існування шакала i зумовлені виключно можливостями доступу до первинного об'єкта. Здобуті особини шакала були досліджені в зоні морського узбережжя - від устя Тилігульського лиману до Березанського та Бузького лиманів і далі на північ вздовж Південного Бугу.

Методичною основою досліджень слугували польові та лабораторні методи, спрямовані на вивчення екологічної ролі та біоценотичних взаємозв'язків шакала в природному середовищі, а також методи паразитарного i серологічного контролю тварин. Всього за 5 років виконано майже 130 діб польових досліджень, оглянуто та піддано лабораторним експертизам біологічний матеріал від 11 особин шакала, здобутих у межах вказаної території. Виявлено, обліковано та обстежено численні схованки цих тварин - в очеретах, скиртах, балках, у покинутих норах лисиць тощо.

В літньо-осінній період 2018 р. у районі лівого берега Березанського лиману були застосовані 3 нічні фотопастки Moultrie Game Spy M-880 Gen1, які розміщували на маршрутах нічних переходів шакала вздовж берегової лінії. Сумарно за 67 ночей 3 допомогою фотопасток 15 разів фіксовано проходження поодиноких дорослих тварин. Аналогічні обліки 3 допомогою фотопасток були проведені в серпні-листопаді 2018 року власниками мисливських угідь на правому березі Південного Бугу
- від села Петрово-Солониха на північ до села Трихати, згідно з якими було обліковано 9 дорослих особин шакала.

При обстеженні здобутих мисливцями особин проводили загальний огляд щодо пошуку ектопаразитів, стосовно яких виконували попередні обліки i відбирали ектопаразитів для подальшої ідентифікації. Для пошуку можливої присутності ектопаразитів та гніздо-норових кліщів відбирали проби детритного матеріалу зі схованок i нір. Дослідження базували на вимогах діючих настанов щодо обліку та ідентифікації ектопаразитів тварин.

У здобутих особин шакала 3 дотриманням усіх вимог у стерильний шприц шляхом пункції серця відбирали проби крові, всього вдалось взяти 9 проб. Отриману сироватку доставляли до лабораторій, де іiі досліджували на антитіла до бруцел (стандартний антиген), до збудника бешихи (з живою тесткультурою та контролями з позитивною сироваткою), до збудників лептоспірозу з тест-штамами 9 серогруп у стандартній реакції мікроаглютинації (РМА) згідно 3 вимогами діючої "Настанови 3 лабораторної діагностики лептоспірозу” (1996 р.).

Через трофейну цінність здобутих мисливцями шакалів їх секційні дослідження не проводили.

\section{Результати та її обговорення}

Узагальнені результати 6-річних досліджень свідчать, що в Дністер-Бузькому межиріччі існує повноцінна саморегулююча і досить щільна популяція C. aureus, яка досі не втрачає темпів інтенсивного розмноження. Практично до 1.01.2019 випадки відлову шакалів мали місце по всіх районах Одеської та Миколаївській областей, особливо вздовж долини Дністра та Південного Бугу. Для Херсонської та Запорізької областей територія найчастішого відлову даного звіра - місцевість у зоні Подніпров'я та Приазов'я. Також у 2018 р. неодноразово шакала відловлювали в Черкаській, Дніпропетровській та Кропивницькій областях.

У прибережній смузі Дністер-Бузького межиріччя сучасна численність шакала досить висока і сумарно оцінюється в 120-140 особин, обсяги щорічного приросту не менше ніж 200\%. Рівень щорічного відлову у 2014-2018 рр. на цій території складав від 14 до 30 особин, певно, ще до 30 особин гине на автошляхах та як підранки, не потрапляючи до рук мисливців. Цілком вірогідно, що має місце загибель шакала від антагонізму вовка, але достовірні дані його прямого знищення цим хижаком у зоні досліджень відсутні.

Аналіз ситуації щодо поширення шакалу в регіоні показує на явно виражену західну магістраль проникнення виду в бік Нижнього Побужжя - зі сторони Дунай-Дністровського межиріччя (рис.1), яке ймовірно слугувало первинним резервуаром для закріплення першої хвилі тварин-мігрантів наприкінці дев'яностих років. 


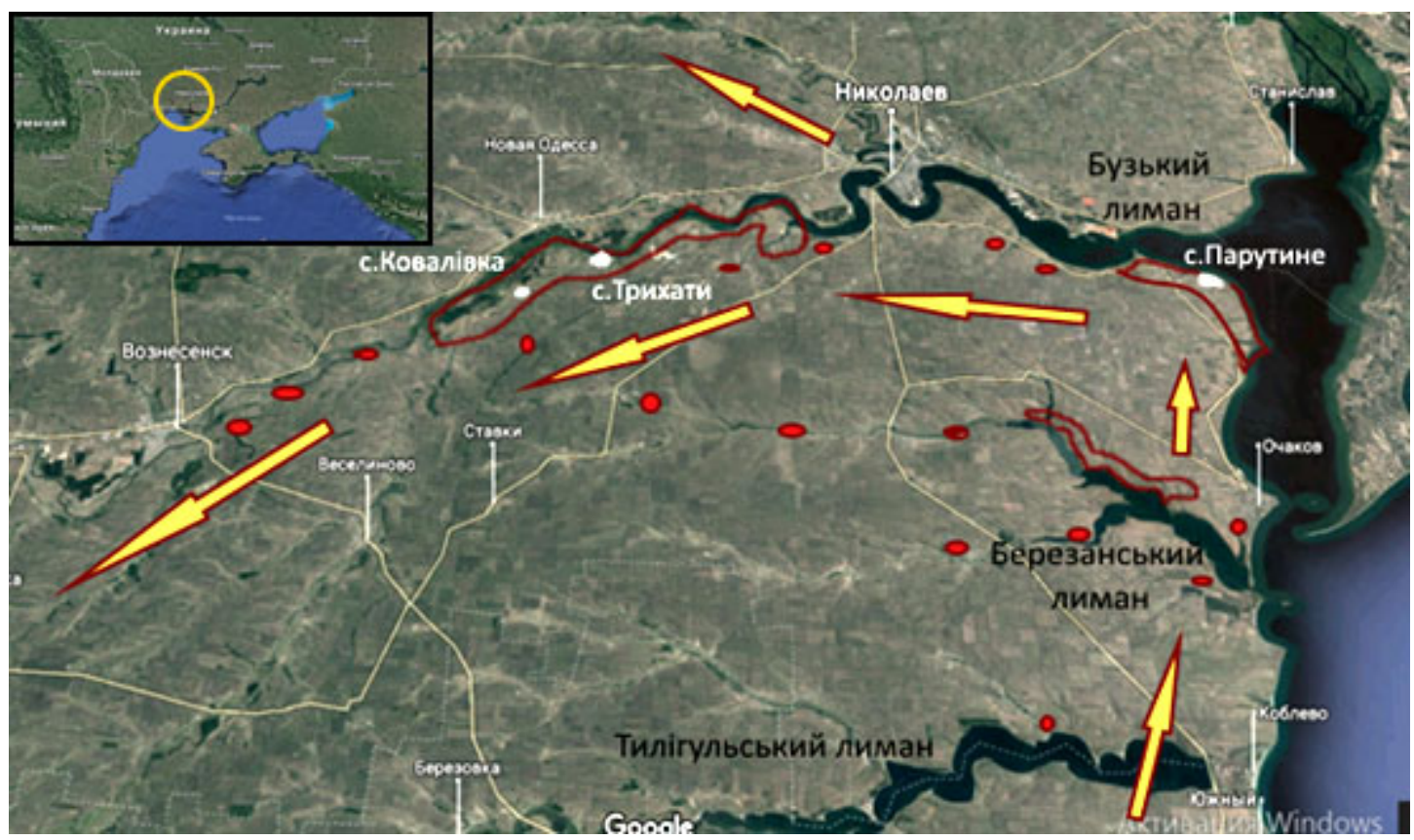

Рис. 1. Поширення шакала (стрілками), основні 3 ділянки осілого існування виду (виділені червоним) та місця візуальної фіксації тварин у 2012-2018рр. (виділені яскраво-червоним)

Наступна хвиля міграції, яка набула розвитку 3 2011-2012 рр., відбувалась із Дністровських плавнів вздовж морського узбережжя на північний схід у напрямку Побужжя. Практично донині шакал відсутній на лівому березі Бузького лиману - у Бузько-Дніпровському межиріччі, в дельті Дніпра та на Кінбурні, що також вказує на західний міграційний коридор з боку Дунаю. Наявність підтверджених носіїв східних гаплогруп у Нижньому Подніпрові та в Приазов’ї (Voloh, 2014) є фактом, який свідчить, що саме в цій місцевості відбулось зімкнення представників 3 обох первинних ареалів Балканського та Кубано-Кавказького.

Судячи з розташування місць зустрічей та відлову шакала, основні осередки осілого існування цих тварин у Дністер-Бузькому межиріччі розташовані на прирічних та прилиманних схилах, порізаних глибокими балками, порослих густими чагарниками, очеретом і прибережно-водною рослинністю. Восени та взимку постійно зустрічаються окремі особини шакала на околицях сільських населених пунктів, а також у виноградниках, садах, лісосмугах. Дана сезонно-просторова розосередженість місцевої субпопуляції $C$. aureus вказує на значущість синантропних кормових джерел, якими слугують різного роду звалища на околицях сіл, сади, виноградники, гущавина берегових схилів та плавневі біотопи. Останні $є$ не просто важливими кормовими стаціями, а й вирізняються високими захисними властивостями, дефіцитними в умовах відкритого степо-польового ландшафту. Особливо часто шакали лишаються на днівку в садах та виноградниках, які привабливі для них завдяки залишкам неприбраного винограду, високою численністю курганчикових мишей i cipoï полівки, сірої куріпки та зграй зимуючих шпаків. Саме в цих біотопах була відстріляна основна маса здобутих звірів.

Загалом у процесі міграційного розселення в Північному Причорномор’ї C. aureus демонструють чітку стаціальну залежність від зволожених i гідроморфних ландшафтів. Місцями основного існування шакала є прибережні, острівні та річководолинні тугаї, традиційні для даного виду на всій північно-європейській та північно-азійській межах первинного ареалу (Okulova et al., 2016). Саме наявності цих біотопів відповідає і структура шляхів первинного, а тепер вже i вторинного розселення шакала - 3 прибережно-дельтових південноукраїнських осередків на північ по долинам Дунаю, Дністра, П. Бугу і Дніпра та їх притоків. Повсюдно ключовим елементом придатності місцевості для заселення $є$ наявність у ній масивів густої високорослої річково-болотної та балкової рослинності. В суцільних лісах і в посушливих степопольових рівнинах Північно-Західного Причорномор'я шакал відсутній.

Шакал не боїться населених пунктів, але і не проявляє явного синантропізму. Випадки нічного шкідництва шакала в населених пунктах відомі щорічно і фіксовані в період із листопада до березня, але все ж лишаються поодинокими. Основними об'єктами нападу є свійська птиця та кролі. Випадки нападу шакалів на кіз, овець, телят поки що невідомі.

Огляд здобутих особин та порівняння 3 даними визначника (Kuznecov, 1975) дійсно підтверджує їх належність до виду Canis aureus, але показує деякі відмінності в екстер'єрі (табл.1) порівняно з описом, наведеним А.M. Волохом (Voloh, 2014). Серед 11 оглянутих тварин лише в 3 -х дорослих особин (2 самці та 1 самка) було типове, яскраво контрастне триколірне золотисто-чорно-сіре забарвлення 3 добре вираженим темним “ременем” по спині та ознаками 
темно-контурної лицевої “маски” вовчого типу. Всі інші оглянуті особини були досить рівного, згладженого тьмяно-сірого кольору, без різко вираженого золотистого чи чорно-темного забарвлення кінчиків остьового волосся, 3 добре помітним світлим підшерстком на животі, віком до двох-трьох років.

\section{Таблиця 1}

Результати замірів тіла шакалів, здобутих у 2012 2018 pp.

\begin{tabular}{|c|c|c|c|c|c|}
\hline Показники & Стать & $\mathrm{n}$ & Med & Min & Max \\
\hline \multirow{2}{*}{ Маса тіла, кг } & $\hat{0}$ & 7 & 10,5 & 7,9 & 14,8 \\
\hline & o & 4 & 9,2 & 8,4 & 10,9 \\
\hline \multirow{2}{*}{ Довжина тіла, см } & $\hat{\sigma}$ & 7 & 73,2 & 68,5 & 79,0 \\
\hline & q & 4 & 72,1 & 65,5 & 77,4 \\
\hline \multirow{2}{*}{ Висота в плечах, см } & $\hat{0}$ & 7 & 49,1 & 44,3 & 56,5 \\
\hline & 우 & 4 & 44,3 & 40,0 & 50,1 \\
\hline \multirow{2}{*}{ Охват тулуба, см } & $\hat{\sigma}$ & 7 & 52,6 & 60,3 & 68,8 \\
\hline & q & 4 & 44,8 & 40,2 & 54,6 \\
\hline \multirow{2}{*}{ Довжина хвоста, см } & $\hat{\sigma}$ & 7 & 23,4 & 22,5 & 28,7 \\
\hline & 우 & 4 & 22,0 & 20,7 & 28,0 \\
\hline \multirow{2}{*}{ Довжина стопи, см } & $\hat{O}$ & 7 & 15,2 & 14,9 & 16,8 \\
\hline & 오 & 4 & 13,5 & 13,0 & 15,9 \\
\hline Довжина (висота) & $\sigma^{+}$ & 7 & 6,8 & 6,0 & 8,7 \\
\hline вуха, см & 우 & 4 & 6,2 & 6,0 & 8,0 \\
\hline
\end{tabular}

Різниця між дорослими самцями і самками, а також між ними та молодими звірами значно виражена, при цьому в самців, навіть у молодих, помітним є більш грубий тип конституції. Самки на 25-35\% поступаються самцям за масою тіла та розмірами голови і в холці, слід самок також помітно менший, ніж у самців, а сама стопа $є$ більш стиснутою.

При уважному огляді тіл здобутих тварин у всіх 11 оглянутих шакалів знаходили бліх, переважно в районі черева. Детальні кількісні обліки цих ектопаразитів шляхом вичісування хутра не проводили, але їх орієнтовні підрахунки свідчать про відносно низьку численність (25-40 особин в районі черева). Відібрані в пробірки, фіксовані та досліджені під мікроскопом ектопаразити віднесені в 6 випадках до бліх виду Ctenocephalides canis, в 2 випадках - до виду Pulex irritans, по 1 випадку Paraceras melis та Hoplopsylla affinis. На трьох особинах молодих шакалів були одночасно знайдені блохи Ctenocephalides canis та Pulex irritans. Таким чином встановлено, що шакал $є$ носієм видоспецифічних видів бліх псових і гризунів, а також вільноживучих бліх Pulex irritans. Всі ці види бліх можуть виступати як об'єкти біологічної трансмісії в колах спонтанної циркуляції збудників природно-осередкових зоонозів, забезпечуючи їх міжвидову міграцію та короткочасну резервацію (Petrishheva, 1967).

Жодного разу на оглянутих тілах шакалів не було виявлено німф та імаго іксодових кліщів, що, вірогідно, пов'язано 3 осінньо-зимовим сезоном полювання, але, безперечно, шакал через стаціальну специфіку не може лишатись осторонь весняно- літньої циркуляції степових іксодид. Так, на декількох тваринах, зафіксованих фотопастками влітку з близької дистанції (1-2,5 м), добре помітні голови звірів, на кінчиках вух яких було 1-2 дорослих кліща. Через особливості інфрачервоного спалаху та відповідного знімка неможливо чітко деталізувати видову належність цих кліщів, але за аналогіями ї знаходження у собак, які використовуються пастухами - це безперечно представники групи Dermacentor marginatus, які є типовим для степової смуги Північного Причорномор'я (Kolonin, 1984).

В 19 пробах підстилки, взятих із літніх схованок шакала наземного типу, розташованих в чагарниках на схилах Бузького лиману, в 2 випадках обліковані дрібні гамазиди, перші з яких віднесені до виду Haemogamasus nidi, а другі - до виду Laelaps hilaris. Взаємозв'язок цих гамазид із шакалом, певніше його схованками, сумнівний - це явно випадкові мешканці (Zemskaja, 1973).

Потенційно висока роль шакала як хазяїна, на якому живляться кліщі, вимагає розширених детальних досліджень, які певно нададуть цікаві та інформативні результати щодо його ролі в степових і навколоводних паразитоценозах. Не менш важливою може бути i роль шакала в колах трансмісивної циркуляції збудників природно-осередкових вірозів та протозоозів, підтримуваних кровосисними комахами зволожених ландшафтів - комарами родини в Culex i Aedes (Olsuf'ev \& Dunaeva, 1962). Потенційно не менш небезпечною може бути в Північному Причорномор'ї роль шакала як хазяїна численних ендопаразитів - від збудників бабезіозу та піроплазмозу до трематодозів та цестодозів, що $\epsilon$ характерними “супутниками” цього хижака в зоні первинного ареалу. Будь-яких, навіть орієнтовних, даних із вказаних питань для південно-української популяції Canis aureus поки що немає.

У реальній сучасній епізоотичній ситуації в регіоні найбільш небезпечною є роль шакала як потенційного хазяїна і носія вірусу сказу, хоча донині лабораторно підтверджених випадків не зареєстровано. При цьому потрібно відмітити, що виникнення хвилі активації сказу восени 1999 року співпало з початком фази інтенсивного поширення шакала на Півдні України (Nakonechnyi \& Lezhneva, 2008). 3 іншого боку, неможливо, щоб такий чутливий до сказу вид, яким $€$ шакал, перебуваючи на території епізоотично активної циркуляції вірусу сказу, залишався поза межами цього процесу. Окрім цього, дисперсна, сімейно-групова специфіка просторової організації популяції шакала та ії висока міграційна активність $€$ факторами, що прямо стимулюють епізоотичну небезпеку участі виду в природних полігостальних осередках сказу, характерних для степової місцевості (Nakonechnyi, 2007).

Результати лабораторних досліджень проб крові шакала, спрямовані на пошук специфічних антитіл до низки природних інфекційних нозоформ, типових для Північно-Західного Причорноморя, відображені в таблиці 2. 
Таблиця 2

Результати серологічних досліджень крові шакала Canis aureus

\begin{tabular}{|c|c|c|c|c|c|c|c|c|c|c|c|}
\hline \multirow[b]{3}{*}{ № } & \multicolumn{11}{|c|}{ Наявність специфічних антитіл до: } \\
\hline & \multirow[b]{2}{*}{$\begin{array}{c}\text { Еризіпело } \\
\text { триксу, } \\
\text { (РІД, } \\
\text { нативний } \\
\text { антиген, } \\
\text { сироватка } \\
1: 10)\end{array}$} & \multirow[b]{2}{*}{$\begin{array}{c}\text { Бруцел } \\
\text { (РІД, } \\
\text { єдиний } \\
\text { антиген, } \\
\text { сироватка } \\
1: 10 \text { ) }\end{array}$} & \multicolumn{9}{|c|}{ Лептоспір (в РМА, сироватка 1:50, ++ і вище) } \\
\hline & & & $\begin{array}{c}0 \\
0 \\
0 \\
0 \\
\vdots \\
0 \\
0 \\
\vdots \\
0 \\
0\end{array}$ & 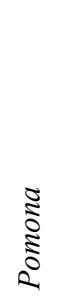 & 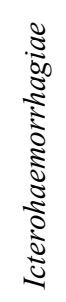 & 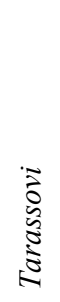 & 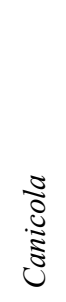 & 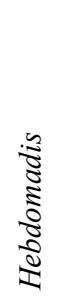 & 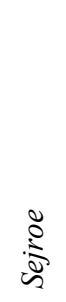 & 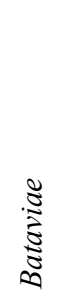 & 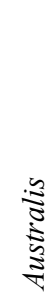 \\
\hline 1 & + & - & + & & & & + & & & & \\
\hline 2 & + & - & & & + & & + & + & & & \\
\hline 3 & - & - & & & & & & & + & & \\
\hline 4 & + & - & & & & & + & & & + & \\
\hline 5 & - & - & & & + & & & & & + & \\
\hline 6 & - & - & + & & & & + & & & & \\
\hline 7 & - & - & & & & & & + & + & + & \\
\hline 8 & + & - & & & & & & & & & + \\
\hline 9 & + & - & + & & & & & + & & & \\
\hline Всього & 5 & 0 & 3 & 0 & 2 & 0 & 4 & 3 & 2 & 3 & 1 \\
\hline
\end{tabular}

За результатами лабораторних експертиз проб сироваток крові шакалів встановлена наявність антитіл до збудника бешихи в 5 (55,5\%) випадках. Контроль проводили в стандартній РІД, використовуючи як антиген змив нативної культури (на МПА) 3 концентрацією за стандартом каламутності 10 млн м.т./1 мл. Тест-культура являє собою польовий ізолят 2012 року, представник серогрупи В. Облік реакції в +++ i вище, перше i єдине розведення сироватки 1:10. Контролі позитивна гіперімунна сироватка в розведенні 1:100 та $1: 1000$.

В реакції 3 єдиним бруцельозним антигеном специфічних антитіл не виявлено. Позитивні контролі - за стандартним набором реагентів (антиген та позитивна сироватка).

На лептоспіроз дослідження виконані в реакції мікроаглютинації та лізису, яку проводили 3 тестштамами 9 серогруп та відповідними контролями в розведенні 1:50 (з антигеном). Специфічні протилептоспірозні антитіла виявлені у всіх 9 досліджених пробах сироватки, ступінь реакції складала від “++” до “++++”. Подальші розведення сироватки від рівня 1:50 не виконували. Більшість (7 iз 9) проб сироваток проявляли реакції до тест-штамів 2-3 серогруп одночасно. Переважання антитіл до серогруп Grippotyphosa, Hebdomadis, Sejroe, Bataviae, хазяями яких є мишовидні польові гризуни, вказує на трофічну природу антигенних контактів. Антитіла до лептоспір серогрупи Canicola, навпаки, демонструють імунологічні наслідки носіння лептоспір, які на півдні України належать до групи інфекційних паразитів, видоспецифічних для тварин родини псових. Аналогічне поширення антитіл до лептоспір Canicola характерне в степовій зоні для лисиці та вовка, тимчасом як у свійських тварин, синантропних i польових гризунів подібні антитіла відсутні.
Таким чином, ситуація з сучасним проникненням на територію Південної України нового для місцевих біоценозів виду - шакала звичайного Canis aureus $€$ яскравим відображенням динамічності біотичних компонентів природних екосистем в умовах їх природної (в даному випадку кліматичної) та антропогенної деструкції. При цьому ландшафтна мозаїчність території регіону є головною причиною того, що існуючий комплекс природно-осередкових зоонозних інфекцій $\epsilon$ значно різнорідним за біоценотичними зв'язками збудників та їх резервуарних носіїв. Аналіз цих зв'язків щодо екологічної специфіки нового компонента фауни степу - шакала показує, що даний вид прямо та опосередковано, через місцеві елементи біологічної трансмісії, поєднує типологічно різні осередки природних інфекцій - степові, польові та навколоводні. Відповідно, епізоотична роль шакала досить суттєва i зумовлена його стаціальними i трофічними взаємозв'язками 3 резервуарними видами тварин, які є хазяями збудників місцевих природноосередкових інфекцій та інвазій, а також важлива й як самостійного хазяїна. Не менш важливим також $\epsilon$ значення шакала як живителя кліщів та ектопаразитів, здатних брати участь у колах циркуляції збудників туляремії, геморагічної лихоманки Конго-Крим, бешихи, лептоспірозу тощо.

\section{Висновки}

1. Новий для України вид - шакал Canis aureus несе значний потенціал епізоотичної загрози як хазяїн i носій збудників природно-осередкових зоонозних інфекцій та інвазій, найбільш небезпечним 3 яких $є$ сказ;

2. Формування на Півдні України стійких осередків існування даного виду зумовлює його 
участь в місцевих паразитоценотичних утвореннях як хазяїв полівидових ектопаразитів, що підтримують циркуляцію збудників низки трансмісивних інфекційних нозоформ;

3. Результати серологічного контролю проб сироваток крові шакалів свідчать про їхню участь у підтримці організменної фази циркуляції збудника бешихи та лептоспір 7 серогруп.

Перспективи подальших досліджень полягають в системному моніторингу та деталізації екологоепізоотичної ролі нового виду - шакала Canis aureus i його участі в паразитозах місцевих екосистем півдня України.

\section{References}

David, A.I. (1982). Formirovanie teriofauny Moldavii v antropogene. Kishinjov (in Russian).

Domnich, V.I., Ruzhilenko, N.S., \& Smirnova, I.O. (2009). Osoblyvosti ekolohii shakala zvychainoho (Sanis aureus L.) na ostrovi Biriuchyi. Visnyk Zaporizkoho natsionalnoho universytetu, 1, 40-47 (in Ukrainian).

Dzuev, R.I., Suhomesova, M.V., \& Hulamhanova, M.M. (2011). Hromosomnyj nabor i nekotorye voprosy jekologii obyknovennogo ili aziatskogo shakala (Sanis aureus Linneus,1758) na Severnom Kavkaze. Jug Rossii, 78-82 (in Russian).

Kirikov, S.V. (1959). Izmenenija zhivotnogo mira v prirodnyh zonah SSSR (13-19 vv.). Stepnaja zona i lesostep. Moskva (in Russian).

Kolonin, G.V. (1984). Rasprostranenie iksodovyh kleshhej. Moskva (in Russian).

Kucheruk, V.V. (1959). Stepnoj faunisticheskij kompleks mlekopitajushhih i ego mesto $\mathrm{v}$ faune Palearktiki. Geografija naselenija nazemnyh zhivotnyh i metody ego izuchenija. Moskva, 45-87 (in Russian).

Kuznecov, B.A. (1975) Opredelitel' pozvonochnyh zhivotnyh fauny SSSR. Moskva, (3) Mlekopitajushhie (in Russian).

Nakonechnyi, I.V. (2007). Ekoloho-heohrafichni ta landshaftno-statsialni zakonomirnosti roztashuvannia i funktsionuvannia oseredkiv osnovnykh pryrodnykh infektsiinykh nozoform pivdnia Ukrainy. Visnyk BDAU, 47, 49-53. (in Ukrainian).

Nakonechnyi, I.V. (2012). Ekoloho-epizootychnyi pidkhid pry epidemichnii otsintsi faunistychnykh uhrupovan stepovoi zony pivdnia Ukrainy. Visnyk Kyivskoho natsionalnoho universytetu im. Tarasa Shevchenka, 60, 35-39 (in Ukrainian).

Nakonechnyi, I.V., \& Lezhneva, I.M. (2008). Ekolohoepizootychni osoblyvosti proiavu skazu tvaryn na terytorii Mykolaivskoi oblasti. Visnyk problem biolohii i medytsyny, 4, 50-54 (in Ukrainian).

Okulova, N.M., Grazhdanov, A.K., \& Neronov, V.V. (2016). Struktura i dinamika soobshhestv mlekopitajushhih Zapadnogo Kazahstana. Moskva (in Russian).

Olsuf'ev, N.G., \& Dunaeva, T.N. (1962). Perenoschiki vozbuditelej prirodno-ochagovyh infekcij. Moskva (in Russian).

Petrishheva, P.A. (1967). Biologicheskie vzaimootnoshenija krovososushhih chlenistonogih $\mathrm{s}$ vozbuditeljami boleznej cheloveka. Moskva (in Russian).

Potish, L.A. (2006). Shakal Canis aureus (Mammalia, Canidae) - novyi predstavnyk fauny Zakarpattia, Ukraina. Vestn. Zoolohii, 10(1), 80-82 (in Ukrainian).

Redinov, K. (2015). Formuvannia oseredku meshkannia shakala (Canis aureus) na pivdni Mykolaivskii oblasti. Pratsi Teriolohichnoi Shkoly, 13, 68-71 (in Ukrainian).

Rozhenko, M.V. (2017). Osoblyvosti povedinky shakala (Sanis aureus 1., 1758) v zoni ekspansii na Pivdni Ukrainy. Pratsi Teriolohichnoi shkoly, 15, 80-85. http://dspace.onu.edu.ua:8080/handle/123456789/123 92 (in Ukrainian).

Rozhenko, N.V, \& Voloh, A.M. (2000). Pojavlenie shakala obyknovennogo (Canis aureus) na juge Ukrainy. Vestnik zoologii, 34(1-2), 125-128. http://dspace.nbuv.gov.ua/handle/123456789/64279 (in Russian).

Voloh, A.M. (2004). Pojavlenie obyknovennogo shakala (Canis aureus) u beregov Kryma. Vestn. Zoologii, 38(3), 80-82. http://elar.tsatu.edu.ua/handle/123456789/4130 (in Russian).

Voloh, A.M. (2014). Ohotnich'i zveri Stepnoj Ukrainy. Herson, 47-52. http://elar.tsatu.edu.ua/handle/ 123456789/4291 (in Russian).

Zemskaja, A.A. (1973). Paraziticheskie gamazovye kleshhi i ih medicinskoe znachenie. Moskva (in Russian). 